\title{
LEGAL PROTECTION OF CONSUMERS THROUGH HALAL CERTIFICATION ON PROCESSED FOOD PRODUCTS IN PALU CITY
}

\author{
Marzuki $^{1}$ \\ ${ }^{1}$ Faculty of Islamic Law, Institut Agama Islam Negeri Palu, Palu, marzuki@iainpalu.ac.id
}

\begin{abstract}
This study discusses legal protection for Muslim consumers through Halal certification in processed food products in Palu. This is based on the writer's concern watching case after case that occurred in the community. With a variety of excuses and interests, the community as consumers become victims of the irresponsible behavior of processed food producers. This research is a normative study combined with empirical research to find out various factors that influence the realization of legal protection for Muslim consumers for processed food products in Palu. Namely: legal substance, Law enforcement officials Related to Halal Certification, Community Legal Culture, and Supporting Facilities. The results showed that the four influential factors had not played their role maximally so that the conclusion was drawn that the legal protection of Muslim consumers through halal certification on processed food products in Palu had not been effective.
\end{abstract}

Keywords: Legal Protection, consumers, halal certification and processed food products

\begin{abstract}
Abstrak. Penelitian ini membahas Perlindungan Hukum Terhadap Konsumen Muslim Melalui Sertifikasi Halal Pada Produk Makanan Olahan di Kota Palu. Hal ini didasari oleh kegelisahan penulis menyaksikan kasus demi kasus yang terjadi di tengah masyarakat. Dengan berbagai dalih dan kepentingan, masyarakat sebagai konsumen menjadi korban dari perilaku produsen makanan olahan yang tidak bertanggung jawab. Penelitian ini merupakan penelitian normatif yang dipadu dengan penelitian empirik untuk mengetahui berbagai faktor yang mempengaruhi terwujudnya perlindungan hukum bagi konsumen muslim terhadap produk makanan olahan di Kota Palu. Yakni: substansi hukum, Aparat pelaksana Hukum Terkait Sertifikasi Halal, Budaya Hukum Masyarakat dan Sarana pendukung. Hasil penelitian menunjukkan bahwa keempat faktor berpengaruh tersebut belum memainkan perannya secara maksimal sehingga ditarik kesimpulan bahwa perlindungan hukum terhadap konsumen muslim melalui sertifikasi halal pada produk makanan olahan di Kota Palu belum efektif.
\end{abstract}


Kata Kunci: Perlindungan Hukum, konsumen, sertifikasi halal dan produk makanan olahan.

\section{Introduction}

The rise of types of processed foods and beverages that are traded freely demands consumers' caution, especially for those who are Muslim. This issue becomes very urgent because the Islamic Sharia has outlined the provisions of the type of food that is halal for consumption. On the other hand, the facts on the ground show several cases of food products claimed by the authorities to contain raw materials that are not halal consumed by Muslims.

According to Ceppy Indra Bestari, that this condition is also inseparable from the impact of the development of food technology. As it is known that the development of food technology, in addition, to have a positive impact on humans, on the other hand also needs to be examined. One impact is the increasingly complex processing and distribution of food ingredients so that the potential for the use or mixing of illicit materials is higher. This complicates the determination of halal and haram of a food product by the laity because it requires adequate knowledge to know whether the product is halal or not. The safest way, the Muslim community is enough to entrust relevant competent institutions to do so. However, considering that official halal-certified products are still relatively small, because of the urgency of the needs and ignorance, people often easily consider "halal" of a product that has not been halal-certified only based on "assumptions" itself. ${ }^{1}$

Some examples of cases include those published in Khabarislam such as the First; Pork Fat Case ... The pork fat case is not new in Indonesia. Previously, in the '80s, Muslims were shocked by Dr. Tri Soesanto, Unibraw, about the gelatin content in several food products. Second; The Ajinomoto Case. The excitement about illicit food also occurred in Bandung in 1984. At that time, a number of Faculty of Animal Husbandry students examined the merchandise of mobile meatball vendors or who hung around the roadside. About 30 percent of the meatballs sold prove to contain pork. Also the Ajinomoto case, in 2001. The community was caused by a stir, due to the fatwa of the Indonesian Ulema Council, which forbade Ajinomoto. Because, based on Indonesian Ulema Council's research, Ajinomoto's raw material is "suspected" mixed with lard ${ }^{2}$

According to Hasrul, currently, all countries have implemented halal product certification. Like in the United States (US), for example. There, said Hasrul, Jewish-made products are marked with a star symbol that shows the

${ }^{1}$ Pusat Halal.com, "Muslim Indonesia dikepung Produk Pangan Haram”, May 2015.

${ }^{2}$ Khabarislam.wordpress.com, "Kasus Lemak Babi di Indonesia”, May 2015. 
product is halal consumed. Likewise in the UK, there is such a thing as the Halal Food Authority ${ }^{3}$. Now, the halal product guarantee law has been enacted by Law Number 33 of 2014 concerning Halal Product Guarantee.

As a follow up to the issuance of various regulations related to halal food products, the authors feel it is important to conduct research on law enforcement of local food products in Palu. Considerations or reasons that form the basis of research are (1) that Palu is dominated by Muslims. According to 2014, the Central Bureau of Statistics data, the population of Palu is 347,856 inhabitants, and $87,78 \%$ are Muslim. ${ }^{4}$ (2). The population of Palu is very diverse, both in terms of ethnicity and religion. (3) the number of processed food products business that is growing rapidly in Palu. This certainly requires the attention of various parties. Processed food products in Palu include Koko Bakery, Golden Bakery, BNS Bakery, and many more.

\section{Literature Review}

Halal Product Concept

The concept of Halal in the application of halal product policies does not only cover Sharia requirements, but also includes aspects of sustainable hygiene, sanitation, and safety, and also makes halal food easily accepted by consumers who care about food safety and healthy lifestyles ${ }^{5}$. Nowadays Muslim consumers are increasingly aware of the existence of halal food. Muslim awareness is not only related that a food product is halal, but they also have a deep awareness and curiosity regarding the integrity of the halal status produced by a producer that includes all activities involved along the production and supply chain so that the various products they buy truly halal ${ }^{6}$.

The process to halal can be started from the beginning to the end, for example, halal meat products, the preparation process can be started from cutting, which then continues when packing (halal packaging), then the delivery process was also carried out well (halal logistic). The problem of the need for halal logistic services is now increasing due to the demands of the international market

\footnotetext{
${ }^{3}$ Hukumonline.com, “Ketentuan Sertifikasi Produk Halal Tetap Tercantum dalam RUU JPH”, May 2015 .

${ }^{4}$ BPS Kota Palu, Kota Palu Dalam Angka Tahun 2014, 2014.

${ }^{5}$ K. Baharuddin, et. al., "Understanding the Halal Concept and the Importance of Information on Halal Food Business Needed by Potential Malaysian Entrepreneurs.", International Journal of Academic Research in Business and Social Sciences, 5, no. 2 (2015): 170-180.

${ }^{6}$ M. H. Zulfakar, M. M. Anuar, and M. S. A. Talib, "Conceptual Framework on Halal Food Supply Chain Integrity Enhancement.", Procedia - Social and Behavioral Sciences, 121, (2014): 58-67, doi: https://doi.org/10.1016/j.sbspro.2014.01.1108
} 
segment for halal products. ${ }^{7}$ The process of sending halal products should not be done by mixing with non-halal products. Even if shipping is done simultaneously, it is necessary to have special treatment for halal food products so as not to mix with non-halal products.

However, along with the development of time and increasing awareness of the Muslim community towards the needs of halal products, the concept of halal has also penetrated various other fields not only in the form of tangible products but also has entered into aspects of services, such as halal tourism. ${ }^{8}$ As a result, sharia hotels and halal restaurants appear. ${ }^{9}$ In this case, Islamic hotels apply sharia values in providing services to the public such as unmarried male and female guests may not be in one room. Then for halal restaurants, restaurant managers are required to have knowledge of halal food requirements according to Islamic law.

Thus the concept of halal in this paper can be concluded as a product or service whose preparation, supply, and distribution is carried out according to Islamic principles in Islam. In other words, producers of products and services always refer to Islamic sharia values in producing and selling their products and services to the Muslim community. Thus the Muslim community can apply their belief in getting various products and services in the world of commerce.

${ }^{7} \mathrm{~K}$. Bonne and W. Verbeke, "Muslim Consumer Trust in Halal Meat Status and Control in Belgium." Meat Science, 79, No. 1, (2008): 113-123. doi: https://doi.org/10.1016/j.meatsci.2007.08.007; K. Nakyinsige, Y. B. C. Man, and A. Q. Sazili, "Halal Authenticity Issues in Meat and Meat Products.", Meat Science, 91, No. 3, (2012): 207-214. doi: https://doi.org/10.1016/j.meatsci.2012.02.015; M. S. A. Talib, and M. R. M. Johan, "Issues in Halal Packaging: A Conceptual Paper." International Business and Management, 5, No. 2, (2012): 94-94.; H. S. Jaafar, et. al., Innovation in Logistics Services - Halal Logistics, (Kuala Lumpur: Universiti Teknologi MARA., 2011), p. 13; R. Kamaruddin, H. Iberahim, and A. Shabudin, "Willingness to Pay for Halal Logistics: The Lifestyle Choice." Procedia - Social and Behavioral Sciences, 50, (2012): 722-729. doi: https://doi.org/10.1016/j.sbspro.2012.08.075

${ }^{8} \mathrm{M}$. Battour and M. N. Ismail, "Halal tourism: Concepts, Practises, Challenges and Future." Tourism Management Perspectives, 19, (2016): 150-154. doi: https://doi.org/10.1016/j.tmp.2015.12.008; H. El-Gohary, "Halal Tourism, is it Really Halal?" Tourism Management Perspectives, 19, (2016): 124-130. doi: https://doi.org/10.1016/j.tmp.2015.12.013; A. Mohsin, N. Ramli, and B. A. Alkhulayfi, "Halal Tourism: Emerging Opportunities." Tourism Management Perspectives, 19, (2016): 137-143. doi: https://doi.org/10.1016/j.tmp.2015.12.010; Z. Samori, N. Z. Md Salleh, and M. M. Khalid, "Current Trends on Halal Tourism: Cases on Selected Asian Countries." Tourism Management Perspectives, 19, (2016): 131-136. doi: https://doi.org/10.1016/j.tmp.2015.12.011.

${ }^{9}$ S. Z. S. Marzuki, C. M. Hall, and P. W. Ballantine, "Measurement of Restaurant Manager Expectations toward Halal Certification Using Factor and Cluster Analysis." Procedia - Social and Behavioral Sciences, 121, (2014): 291-303. doi: https://doi.org/10.1016/j.sbspro.2014.01.1130; S. Zannierah Syed Marzuki, C. M. Hall, and P. W. Ballantine, "Restaurant Managers' Perspectives on Halal Certification." Journal of Islamic Marketing, 3, No. 1, (2012): 47-58. doi: doi:10.1108/17590831211206581 


\section{Halal Food Products in Sharia Concepts}

Food Industry is an industry that includes the processing of agricultural products, plantations, and fisheries into food and also includes semi-finished products that do not directly become food products. ${ }^{10}$ Today's food industry has become one of the fastest-growing industries today. The process of giving birth to halal food products not only starts from the source of food it originates but also includes the process of packing, distribution, processing to the presentation.

The word Halal, according to some opinions, comes from the root of the which means (الحل word (الإباحة) something that is permissible according to the Sharia. Aljurjani wrote, the word halal comes from the word الحلد which means "open" (الإباحة). In terms, it means that every non-sanction is used or something that the Sharia is free to do. (Ali, 2019). In the Qur'an Surah Al-A'raf [7]: 157. Allah says: "And (Allah) justifies for them all that is good and forbids them all that is bad.

The importance of halal labeling of food is a guarantee in consumers to choose food to be consumed, especially Muslims. As contained in the Al-Qur'an Surah Al-Baqarah [2]: 168.

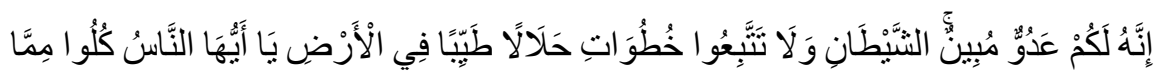

That means:

"O people! Eat of the good and permissible food on earth and do not follow the steps of Satan. Indeed, Satan is a real enemy to you." (Surat al-Baqarah: [2]: 168)

Amid a smart and selective society, halal certification is a must. The problem is then, there are still many entrepreneurs, especially from small and medium businesses who do not understand the procedures for the administration and the meaning of halal certification.

So it can be concluded that the Halal Food Industry is a business management activity that is producing, making, or producing goods based on sharia principles that prioritize the halal of a product or food, as well as obtaining halal certification from LP POM Indonesian Ulema Council as a proof that the products being traded have met the halal conditions set by the Indonesian Ulema Council Fatwa.

${ }^{10} \mathrm{~B}$. Bigliardi and F. Galati, "Innovation Trends in the Food Industry: The Case of Functional Foods.", Trends in Food Science \& Technology, 31, No. 2, (2013): 118-129. doi: https://doi.org/10.1016/j.tifs.2013.03.006; H. A. Bremner, "Toward Practical Definitions of Quality for Food Science.", Critical Reviews in Food Science and Nutrition, 40, No. 1, (2000): 83-90. doi: 10.1080/10408690091189284; R. W. Hutkins, R. W., et. al., "Prebiotics: Why Definitions Matter." Current Opinion in Biotechnology, 37, (2016): 1-7. doi: https://doi.org/10.1016/j.copbio.2015.09.001 


\section{Definition and Legal Basis of Consumer Protection}

With the issuance of Law Number 8 of 1999 Concerning Consumer Protection (hereinafter referred to as Law No. 8 of 1999 concerning Consumer Protection), Indonesia already has a Law specifically regulating the legal protection of Consumers.

In Article 1 of Law No. 8 of 1999 concerning Consumer Protection explains the notion of consumer protection, namely all efforts that guarantee legal certainty to provide legal protection to consumers.

Legal protection for consumers is a form of legal certainty from the state in protecting its citizens. Legal protection can be done by giving restrictions to the citizens of what can and may not be done, as well as the certainty of the legal protection.

Furthermore, the understanding of consumers is regulated in Article 1 paragraph 2 of the Consumer Protection Law No. 8 of 1999, namely every user of goods and/or services available in the community, both for the benefit of themselves, their families, other people, and other living things and not for trade. In the explanation of the Consumer Protection Law No. 8 of 1999 stated that the intended consumers are end consumers, that is, the end-users of a product or service. While intermediary consumers are consumers who use a product as part of the production process of another product.

In the economic literature, there are two consumers, namely the end consumer and intermediate consumers. End consumers are end-users of a product, while intermediate consumers are consumers who use a product as part of the production process of another product. In the law of consumer protection, the intended consumer is the final consumer.

\section{Consumer Rights and Obligations}

In principle, consumer protection as stipulated in Law No. 8 of 1999 concerning Consumer Protection in Article 2 explains the principles of benefit, fairness, balance, security and consumer safety, and legal certainty. Whereas in Article 3 of Law No. 8 of 1999 the objectives of consumer protection are:

a. Increase awareness, ability, and independence of consumers to protect themselves.

b. Raise the dignity of consumers by avoiding the negative effects of using goods and services.

c. Increasing consumer empowerment in choosing, determining, and claiming rights as consumers. 
d. Creating a consumer protection system that contains elements of legal certainty and information disclosure as well as access to obtain information.

e. Growing awareness of businesses about the importance of consumer protection so that honest and responsible attitudes grow in the business.

f. Improving the quality of goods and or services that ensure the continuity of the business of producing goods or services, health, comfort, security, and consumer safety.

Consumer Rights according to article 4 of Law Number 8 of 1999 concerning Consumer Protection are:

a. The right to comfort, security, safety in consuming goods, and or services.

b. The right to choose goods and or services and to obtain goods or services in accordance with the exchange rate and conditions and guarantees promised.

c. The right to true, clear, and honest information about the conditions and guarantees of goods and services.

d. The right to be heard opinions and complaints on goods and services used.

e. The right to get full advocacy, protection, and efforts to resolve consumer protection disputes.

f. The right to consumer education and guidance.

g. The right to be treated or served properly and honestly and not discriminatory.

h. The right to receive compensation if the goods and services received do not comply with the agreement.

i. Rights are regulated in the provisions of other laws and regulations.

The most important of many points of the form of protection, it appears that aspects of consumer comfort, security, and safety are the most basic and main aspects of consumer protection. Goods and services whose use does not provide comfort, moreover that does not provide the same safe or endanger the safety of consumers can not be tolerated legally. To guarantee a product and/or service in its use will be comfortable, safe, and not dangerous, consumers are given the right to choose the goods or services they want based on the disclosure of true, clear, and honest information.

Erman Rajagukguk in Siddharta said that efforts to achieve consumer protection goals need to have arrangements made by: 
1) Creating a consumer protection system that contains an element of open access to information and guarantees legal certainty.

2) Protect the interests of consumers in particular and the interests of businessmen.

3) Improve the quality of goods and services.

4) Provide protection to consumers from deceptive and misleading business practices.

5) Integrate the implementation, development, and regulation of consumer protection with protection fields in other fields. ${ }^{11}$

\section{Halal Certification and Halal Labeling}

Halal certification and halal labeling are two different activities but are related to one another. Halal certification can be defined as a systematic testing activity to find out whether a product manufactured by a company has met the halal requirements. The results of halal certification activities are the issuance of halal certificates if the intended product meets the requirements as a halal product. Halal certification is carried out by institutions that have the authority to implement it.

The ultimate goal of halal certification is the formal legal recognition that the product issued has met the halal requirements. Whereas halal labeling is the inclusion of a written or halal statement on the product packaging to show that the product in question is a halal product. ${ }^{12}$

In Indonesia, the authoritative institution for implementing Halal Certification is the Indonesian Ulema Council which is technically handled by the Institute for Drug and Cosmetics Food Assessment (BPPOM). Whereas halal labeling activities are managed by the Food and Drug Supervisory Agency. In their implementation in Indonesia, halal labeling activities have been implemented before halal certification.

\section{Halal Label as One Protection for Muslim Consumers in Indonesia}

The teachings of Islam globally, has laid down norms for its adherents in various aspects, including in consuming food or drinks must be tayyib, meaning that it is lawful and good, it is a necessity unless someone is in an emergency. Thus, efforts to protect Muslim consumers in Indonesia also need to touch the

${ }^{11}$ Sidharta, Hukum Perlindungan Konsumen Indonesia, (Jakarta: Grasindo, 2000), p. 7

${ }^{12} \mathrm{http}: / /$ lppommuikaltim.multiply.com/journal/item/14/Sertifikasi_dan_Labelisasi_Hala l, May, 2015. 
issue of halal products. The halal guarantee of a food product can be realized, among others, in the form of halal certification that includes a food product with the certification the manufacturer can put halal writing/label on the packaging. Knowing a food product is halal or not halal for Muslims can generally be known through the inclusion of halal labels on product packaging. The word halal in Arabic script on the label of a food product is usually found by consumers in packaging as a form of a statement from the producer indicating that the product is safe for consumption by Muslims, or avoiding the elements as prohibited by Islamic teachings.

Halal provisions for Muslims in consuming a product include various aspects, including aspects of raw materials, aspects of the procedures for producing them, aspects of the procedures for serving them, to aspects of the procedures for consuming them. While the halalness of a product stated in a label, emphasizes the halalness according to the elements of the raw material and how to produce it, including how to package it.

Based on applicable regulations, the halal label that is included in a food product in the packaging must be based on the halal certificate owned by the product in question where the halal certificate is issued by the competent institution namely the Food, Drug and Cosmetics Research Institute of the Indonesian Ulema Council.

Processed food products that can be submitted for halal certification and labeling are:

1. Products that have been registered with the Food and Drug Administration (have MD for domestic products and ML for foreign products).

2. Products that already have Household Industry Food number issued by the Health Service.

The certification is issued by the Indonesian Ulema Council through a series of checks, namely the evaluation by the Auditor Team and the Fatwa Commission Meeting, while Halal Labeling is approval for writing the label given based on the Halal Certification issued by the Indonesian Ulema Council, and has implemented a Halal Guarantee System. This is what can provide peace for consumers to consume halal food.

\section{Regulations on Halal Labeling in Indonesian Positive Law}

In the Elucidation of Article 30 paragraph (2) item e the Food Law states that halal information for a food product is very important for the majority of Indonesian people who embrace Islam. However, the inclusion of a new food label is an obligation of everyone who produces food or imports food into Indonesian 
territory for trade states that the food in question is halal for Muslims. Information about halal is intended to prevent people from consuming food that is not halal (haram).

By including halal on the food label, it is assumed that the statement has occurred and everyone who makes the statement is responsible for the truth of the statement. Information on the halal label must be printed in Indonesian, Arabic, and Latin letters in a clear form so that it is easily understood by the public. The use of foreign terms can be done as long as there is no equivalent, cannot be created equivalent, or used for the purpose of food trade abroad. Everyone is prohibited from changing, labeling, or exchanging the date of the month and year when the expiry date of the food is circulated.

The Consumer Protection Act also regulates halal provisions. Regulations regarding halal labeling are included in Chapter IV of the Consumer Protection Act concerning Prohibited Actions for businessmen, namely Article 8 paragraph (1) letter $h$ which states that businessmen are prohibited from producing and/or trading goods and/or services does not follow the provisions of halal production, as stated. In this case, the halter is stated on the label. In this case, the government must also protect the public against the production and distribution of food that does not meet the requirements, especially in terms of quality, health, safety, and religious beliefs. This regulation is confirmed in Presidential Instruction No. 2 of 1991 concerning Improvement of Development and Supervision of Processed Food Production and Distribution. The implementation of halal labeling on food and beverage product packaging is considered very important to provide certainty for Muslims about halal at least for food and beverage products in circulation.

This was realized with the signing of the Cooperation Charter between the Minister of Health, the Minister of Religion, and the General Chairperson of the Indonesian Ulema Council dated June 21, 1996, concerning the Implementation of Halal Writing on Food.

The basic policy of regulating the inclusion of halal labels is to provide peace and certainty, is voluntary, does not add to the price burden for consumers/quality, safe, and lawful. The certainty of halal can be guaranteed because before the product is permitted to bear the halal label, a comprehensive integrated local audit has been carried out by the Joint Team of the Directorate General of Medicines and Food Control, the Ministry of Religion and the Indonesian Ulema Council. The comprehensive inspection includes an audit of raw materials and the application of good manufacturing methods, including laboratory testing. Based on the results of this inspection, Indonesian Ulema Council issued halal certificates for products that fulfill the requirements, which subsequently became the basis for the inclusion of halal labels by the Food and Drug Supervisor Agency. 


\section{Results and Discussion}

Factors Influencing Muslim Consumer Protection through Halal Certification in Palu

Taking into account the real conditions in the field, there are several neutral factors that affect the legal protection of Muslim consumers through halal certification in processed food products in Palu, among others: Legal substance, law enforcement officers, community legal culture, and supporting facilities.

Legal Substance Regarding Consumer Protection through Halal Certification

1. Law Number 8 of 1999 concerning Consumer Protection as discussed in the literature review section.

2. Government Regulation of the Republic of Indonesia Number 28 of 2004 concerning Food Safety, Quality, and Nutrition

3. Law Number 36 of 2009 concerning Health

4. Government Regulation of the Republic of Indonesia Number 69 of 1999 concerning Food Labels and Advertisements

5. Law of the Republic of Indonesia Number 33 Year 2014 Regarding Halal Product Guarantee

In consideration of Law No. 33 of 2014 concerning halal product guarantees, it is explained that:

a. The 1945 Constitution of the Republic of Indonesia mandates the state to guarantee the independence of each resident to embrace their respective religions and to worship according to their religion and belief;

b. That in order to guarantee that every religious adherent to worship and practice the teachings of his religion, the state is obliged to provide protection and guarantee regarding the legality of the products consumed and used by the public;

c. That not all halal products circulating in the community are guaranteed;

d. That the current regulation on the halal status of a product does not guarantee legal certainty and needs to be regulated in a statutory regulation;

e. That based on the considerations as referred to in letter $a$, letter $b$, letter c, and letter d, it is necessary to establish a Law on Guarantee of Halal Products;

The implementation of Halal Product Guarantee is based on:

a. Protection

b. Justice 

c. Legal certainty;
d. Accountability and transparency;
e. Effectiveness and efficiency; and
f. Professionality.

\section{Article 3}

The implementation of the Halal Product Guarantee aims:

a. Provide comfort, security, safety, and certainty of the availability of Halal Products for the public in consuming and using Products; and

b. Increase added value for businessmen to produce and sell Halal Products.

\section{Article 4}

Products that enter, circulate, and trade within the territory of Indonesia must be halal-certified.

The above description shows that, normatively, regulatory support regarding halal food certification is almost adequate. However, the current obstacle is that the halal product guarantee law is not yet effective. This is also in line with the law which explains the closing provisions of Articles 64 and 65 that:

\section{Article 64}

Halal Product Guarantee Agency must be formed no later than 3 (three) years from the enactment of this Law.

\section{Article 65}

Regulations on the implementation of this Law must be stipulated no later than 2 (two) years from the enactment of this Law.

Thus, the public still needs to be patient to wait for the improvement of this regulation by forming the Halal Product Guarantee Agency and its implementing regulations.

\section{Implementers of Rules Regarding Consumer Protection through Halal Certification}

There are at least three important elements that provide a buffer for the realization of legal protection for Muslim consumers through halal certification on processed food products, especially in Palu, namely:

- Institute for Food, Medicine and Cosmetics Study of the Indonesian Ulema Council of Central Sulawesi Province

- $\quad$ Central Sulawesi Food and Drug Supervisory Agency

- $\quad$ Palu City Government Health Service.

These three elements are in direct contact with processed food producers in Palu. The Indonesian Food and Drug Administration and Cosmetics Research Council is responsible for halal certification, the Food and Drug Supervisory 
Agency is responsible for halal product labels as listed on food packaging, and the Palu City Health Office is responsible for licensing and supervision related to health aspects of processed food products.

In accordance with the results of the author's interview with the Central Bureau of Drug and Food Control, in this case, Mr. Jamaluddin Ssi, SH, Apt that up to now there has not been a Memorandum of Understanding, between the Indonesian Ulema Council of Central Sulawesi Province and the Center for Drug and Food Control related to halal certification, although so far have worked together in that field. According to the current arrangement; the Indonesian Food and Drug Administration and the Cosmetics Board of the Ulema Council is responsible for the halal certificate aspect, while the halal labeling is handled directly by the Food and Drug Supervisory Agency. ${ }^{13}$ While the Palu City Government Health Service is responsible for the feasibility of health aspects and product supervision for the home industry.

According to the opinion of the author, in order to provide protection to Muslim consumers related to halal aspects of processed food products, the synergy between the three elements/institutions as mentioned above is needed, namely the Food, Drug and Cosmetics Research Institute of the Indonesian Ulema Council, the Indonesian Drug Supervisory Agency Food and Health Services Palu City Government. The difficulty of the authors to obtain accurate data on the number of processed food businessmen in Palu is due to the lack of coordination between related parties. As an example; licensing and supervision for businesses or home industries are handled by the Health Office, while for the upper-middleclass industries are handled by the Food and Drug Supervisory Agency. Ideally, there is a one-stop institution that houses this matter, or at least a coordinating network between the three elements is harmoniously established.

On the other hand, the number of human resources possessed by the Indonesian Ulema Council for Food, Drugs and Cosmetics Research, the Indonesian Food and Drug Administration, and the Health Office is still limited. Referring to the Decree of the Institute of Food, Drug and Cosmetics Assessment of the Indonesian Ulema Council regarding Inauguration of the Management Structure of the Institute of Food, Medicine and Cosmetics Study of the Indonesian Ulema Council of Central Sulawesi Province, the 2012-2014 Solemnity Period, the number of human resources listed in the decision letter as many as 12 people. This includes the auditor. With a limited amount, with such a large area covering the entire territory of Central Sulawesi, it certainly gives a shadow that these conditions are very difficult to provide maximum results.

Furthermore, judging from the background of the management or manager of the Indonesian Ulema Council for Food, Medicine and Cosmetics Assessment, almost all of them have main tasks, for example as lecturers and Civil Servants in several Ministries. Its existence at the Indonesian Ulema Council's Food, Drugs,

${ }^{13}$ Jamaluddin, Staff of Central Sulawesi BPOM, interviewed by author, September 15, 2015. 
and Cosmetics Research Institute is only an additional task. The consequence is, the lack of time that must be devoted to the interests of the community is related to the task of the Indonesian Institute of Food, Drugs, and Cosmetics Study.

\section{Cultural Law Society}

According to Freidmann, the culture of community law is one important factor for the operation of a legal product in the community. Including all forms of regulations related to halal certification on processed food in Palu, influenced by the legal culture of the local community.

In this section, the community's legal culture is divided into two parts, namely: (1) the community's legal culture in relation to consumers, and (2) the legal culture of the community as a businessmen.

\section{Community Legal Culture in Relation to Consumers}

The author has conducted closed interviews with a number of people as respondents in relation to processed food products in Palu. The answers and responses of the community related to processed food products in Palu can be concluded that although there are concerns in consuming processed food products, due to such high needs, people are forced to consume processed food products.

\section{Community Legal Culture in Relation as a Businessmen}

Departing from the observations and results of open interviews with several businessmen, there were several answers regarding halal certificates. First, some businessmen do not try to issue halal certificates on their processed food products because they assume that halal certificates are not obligatory. Secondly; Some business operators consider that a permit from the Health Office is sufficient for a processed food production business. The reason that their business is regularly inspected/monitored by relevant agencies and declared healthy and lawful. Thus, there are no obstacles for anyone to consume processed food products. Third; They do not understand the procedures that must be taken to obtain halal certificates on processed food products produced.

According to the author's observations, based on data released by the Food, Drug, and Cosmetic Research Institute of the Indonesian Ulema Council, it shows that; Many businesses that are registered as Indonesian Ulema Council's halal certificate holders are actually small businesses whose raw materials are far from non-halal food elements, such as various kinds of beans, coffee powder, coconut flour and so on. While not many products should be prepared for example bread 
and cakes have Halal certificates from the Food, Drug, and Cosmetics Research Institute of the Indonesian Ulema Council.

Supporting Facilities Related to Halal Certification in Processed Food Products in Palu

One important factor that also influences the effectiveness of law in the community is supporting facilities. In connection with halal certification from the Food, Drug, and Cosmetics Assessment Institute of the Indonesian Ulema Council in Palu, there are a number of things that should be noted by the authors. main facilities such as offices do not meet the eligibility standards. Ideally, the Indonesian Food and Drug Research Institute and the Indonesian Ulema Council has adequate office facilities and supporting facilities, so that it is comfortable for all management and auditors. In addition, the people who visited the Indonesian Food and Drug Administration and Cosmetics Research Office also felt comfortable. Second; there should be a laboratory available that allows product testing to be carried out. Third; Need to establish coordination with relevant agencies through an information network concerning data on businessmen as well as for other purposes related to halal certification on processed food products in Palu.

\section{Conclusion}

Based on the description in the previous chapter, the author will formulate the conclusions from the results of this study, that the legal protection for Muslim consumers of food products through halal certification, has not run effectively. There are four factors that become indicators in this research, namely; Legal substance related to halal certification of processed food products, Law enforcement officers related to halal certification, Community Legal Culture, and Facilities and infrastructure

\section{Recommendation}

As per the description above on the conclusions, the author suggests several things: (1). In order for the government to conclude regulations related to halal certification and prepare various provisions to ensure the implementation of legislation related to Halal Product Guarantee. (2). Building coordination between institutions to strengthen synergy in relation to halal certification. (3). Building public awareness in the form of education and outreach so that the community as consumers understand their rights and obligations. (4). The government complements the facilities and infrastructure needed in order to realize legal protection for the community related to halal certification. 


\section{References}

Thihmaz, Abdul Hamid Mahmud, Hidangan Halal Haram Kalangan Muslim, Jakarta: Cendikia Sentra Muslim, 2001.

Miru, Ahmadi and Yodo, Sutarman, Hukum Perlindungan Konsumen, Jakarta: Raja Grafindo, 2004.

Miru, Ahmadi, Prinsip-prinsip Perlindungan Hukum Bagi Konsumen di Indonesia, Disertasi, Surabaya: Program Pascasarjana Universitas Airlangga, 2000.

Baharuddin, et. al., "Understanding the Halal Concept and the Importance of Information on Halal Food Business Needed by Potential Malaysian Entrepreneurs.", International Journal of Academic Research in Business and Social Sciences, 5, No. 2, 2015: 170-180.

Battour, M. and N. Ismail, M., "Halal Tourism: Concepts, Practises, Challenges and Future." Tourism Management Perspectives, 19, 2016: 150-154. doi: https://doi.org/10.1016/j.tmp.2015.12.008

Bigliardi, B. and Galati, F., "Innovation Trends in the Food Industry: The Case of Functional Foods." Trends in Food Science \& Technology, 31, No. 2, 2013: 118129. doi: https://doi.org/10.1016/j.tifs.2013.03.006

Bonne, K. and Verbeke, W., "Muslim Consumer Trust in Halal Meat Status and Control in Belgium." Meat Science, 79, No. 1, 2008: 113-123. doi: https://doi.org/10.1016/j.meatsci.2007.08.007

BPS Kota Palu, Palu Dalam Angka Tahun 2014, 2014.

Bremner, H. A. "Toward Practical Definitions of Quality for Food Science.", Critical Reviews in Food Science and Nutrition, 40, No. 1, 2000: 83-90. doi: $10.1080 / 10408690091189284$

El-Gohary, H., "Halal Tourism, is it Really Halal?" Tourism Management Perspectives, 19, 2016: 124-130. doi: https://doi.org/10.1016/j.tmp.2015.12.013

Susanto, Happy, Hak-hak Konsumen Jika dirugikan, Jakarta: Visimedia, 2008

Hutkins, R. W., et. al., "Prebiotics: Why Definitions Matter.", Current Opinion in Biotechnology, $\quad 37, \quad$ (2016): $1-7 \quad$ doi: https://doi.org/10.1016/j.copbio.2015.09.001

Jaafar, H. S., et. al., Innovation in Logistics Services - Halal Logistics, Kuala Lumpur: Universiti Teknologi MARA, 2011.

Kamaruddin, R., Iberahim, H., and Shabudin, A., "Willingness to Pay for Halal Logistics: The Lifestyle Choice.", Procedia - Social and Behavioral Sciences, 50, 2012: 722-729. doi: https://doi.org/10.1016/j.sbspro.2012.08.075

"Kasus Lemak Babi di Indonesia", Mei, 2015, Khabarislam.wordpress.com. 
Marzuki, S. Z. S., Hall, C. M., and Ballantine, P. W., "Measurement of Restaurant Manager Expectations toward Halal Certification Using Factor and Cluster Analysis." Procedia - Social and Behavioral Sciences, 121, 2014: 291-303. doi: https://doi.org/10.1016/j.sbspro.2014.01.1130

Mohsin, A., Ramli, N., and Alkhulayfi, B. A. Halal "Tourism: Emerging Opportunities." Tourism Management Perspectives, 19, 2016: 137-143. doi: https://doi.org/10.1016/j.tmp.2015.12.010

Nakyinsige, K., Man, Y. B. C., and Sazili, A. Q., "Halal Authenticity Issues in Meat and Meat Products.", Meat Science, 91, No. 3, 2012: 207-214. doi: https://doi.org/10.1016/j.meatsci.2012.02.015

Nasution, Az., Hukum Perlindungan Konsumen: Suatu Pengantar, Jakarta: Daya Widya, 1999

Konsumen dan Hukum: Tinjauan Sosial, Ekonomi dan Hukum pada Perlindungan

Konsumen Indonesia, Jakarta: Pustaka Sinar Harapan, 1995

"Muslim Indonesia dikepung Produk Pangan Haram", Mei 2015, Pusat Halal.com.

Samori, Z., Md Salleh, N. Z., and Khalid, M. M., "Current trends on Halal tourism: Cases on selected Asian countries.", Tourism Management Perspectives, 19, 2016: 131-136. doi: https://doi.org/10.1016/j.tmp.2015.12.011

Shidarta, Hukum Perlindungan Konsumen Indonesia, Jakarta: PT.Grasindo, 2004.

Sidabalok, Janus, Hukum Perlindungan Konsumen di Indonesia, Bandung: PT. Citra Aditya Bakti, 2006.

Syawali, Neni Sri, Hukum Perlindungan Konsumen, Bandung: Mandar Maju, 2000

Sudaryatmo, Masalah Perlindungan Konsumen di Indonesia, Bandung: Citra Aditya Bakti, 1996

Talib, M. S. A., and Johan, M. R. M., "Issues in Halal Packaging: A Conceptual Paper", International Business and Management, 5, No. 2, 2012: 94-94.

Hadad, Tini, Kembalikan Masalah Halal Haram Pada LP-POM MUI, 17 Tokoh Bicara Halal, Jakarta: Info Halal Multimedia, Tanpa Tahun

Tri, Celina, Hukum Perlindungan Konsumen, Jakarta: Sinar Grafika Offset, 2008

Qardhawi, Yusuf, Halal Haram Dalam Islam, Solo: Intermedia, 2003

Yayasan Lembaga Konsumen Indonesia (YLKI), Panca Hak Konsumen, 1995, Jakarta: YLKI

Zannierah, S. Syed Marzuki, Hall, C. M., and Ballantine, P. W., "Restaurant Managers' Perspectives on Halal Certification.", Journal of Islamic Marketing, 3, No. 1, 2012: 47-58. doi: doi:10.1108/17590831211206581 
Zulfakar, M. H., Anuar, M. M., and Talib, M. S. A., "Conceptual Framework on Halal Food Supply Chain Integrity Enhancement." Procedia - Social and Behavioral Sciences, $\quad$ 121, (2014): 58-67. doi: https://doi.org/10.1016/j.sbspro.2014.01.1108

Zumrotin, Penyambung Lidah Konsumen, Jakarta: Puspa Swara, 1996

Law No. 8 Year 1988 about Consumer Protection

Law No. 7 Year 1996 about Food

Law No. 23 Year1992 about Health

Law No. 33 Year 2014 about Halal Product Guarantee

Govt Decree No. 69 Year 1999 about Label and Food Publicity 